\title{
The Importance and Place of Family Farming in the World and in Turkey
}

\author{
Aysun YENER
}

\begin{abstract}
More than 3 billion people in the world live in rural area and nearly 2,5 billion work in the sector of agriculture. Enterprises which make agricultural production have the rank of family farmer. $56 \%$ of total agricultural land is operated by family farming. $85 \%$ of total agricultural area in Asian Countries, $62 \%$ in Africa, $83 \%$ in North and Central America, 68\% in Europe and $18 \%$ in South American countries are run by family farming. In Turkey, $23 \%$ of the population lives in rural area and live off agriculture sector. When all these factors are considered, family farming has an important place throughout the world. Therefore UN and FAO declared the year 2014 "International Year of Family Farming". Though there is not a clear definition of family farming, some countries started their study by making definition of family farming. According to the definition of FAO, disregarding gender, family farming is the vegetable, animal production, fishery and forestry activities carried out by using family labor force. According to the European Commission family farming is accepted as family corporation. In order to keep production sustainable and efficient of family farmers who conduct traditional production, official definition of family farming was done in United States of America and some Southern American countries. Size of land was defined according to income and production resources in Mexico and according to the income of household. Although there is no specific definition of family farming in Asian countries and in Turkey, agricultural family businesses have an important place in the economy of country. Therefore, structure and development of family farming was analyzed depending on the literature.
\end{abstract}

Keywords — Family farming, farming, rural area, Turkey.

\section{INTRODUCTION}

Family farming is the enterprises where family-based activities are run regardless of gender. Family farming which based on family labor force and gives particular importance to sustainability of natural resources and environment has a crucial place throughout the world. Therefore UN and FAO declared the year 2014 "International Year of Family Farming". Of all 570 million agricultural enterprises in the world, 500 million are run by family farming and 457 million enterprises has less than 2 hectars of production field [1], [2], [3]. Family farmers which compose $95 \%$ of total enterprises in the world run $56 \%$ of total land in the sense of agricultural field [4]. Agriculture sector is quite important for countries throughout the world.

Aysun YENER Selçuk University, Faculty of Agriculture, Department of Agricultural Economics (phone: +905305661666 e-mail: aysunyener@ selcuk.edu.tr)
Developing countries compose four third of world agricultural production and agricultural sector covers $30 \%$ of their GDP in most of these countries (1). $23 \%$ of the population lives in rural area in Turkey and live off agricultural production. $99,28 \%$ of nearly 3 million agricultural enterprises are family enterprises. Agricultural sectors covers 8,34\% of GDP [5]. As it can be understood from here, family farming is one of the most effective components of agriculture in food production both in developing and developed countries [6]. In fact, 842 millions of people are starving throughout the world. Therefore, agricultural sector in which food production is done is quite important as main sector [7].

In order to keep production sustainable and efficient of family farmers who conduct traditional production, studies started by making an official definition of family farming which is quite important in the World and in Turkey was done in United States of America and some Southern American countries [8]. There is no clear definition of family farming in Asian countries or in Turkey. With this study, the importance of family farming throughout the world was stated and suggestions were put forward.

\section{FAMILY FARMING ACCORDING TO COUNTRIES}

Since family farming is effective in decreasing poverty, protecting agricultural diversity, food security, sustainability of natural resources and environment, preventing migration from rural to urban area, protection of cultural values; current status of family farming was analyzed according to countries below.

\section{A. Family Farming in European Union}

In AB-28, family farming is defined as agricultural organization where all risks related with agricultural enterprises are adopted. Enterprises which conduct family farming provide majority of their capital from family and most of their income from enterprises. There are 13 million agricultural enterprises in European Union averagely and 97\% of these enterprises are enterprise owners [9]. Average land width of these enterprises is 14,2 hectare and $85 \%$ conduct family farming. $68 \%$ of total agricultural land is run [10]. 


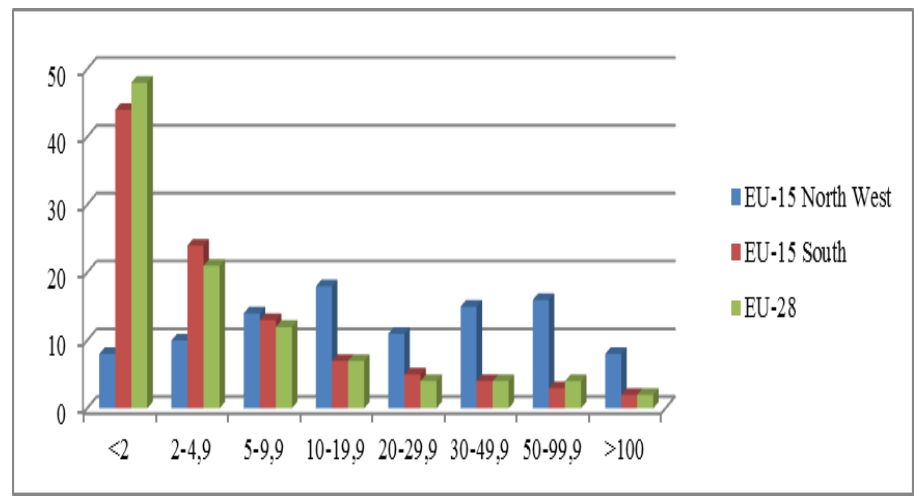

Resource: [9].

Fig. I Distribution of Enterprises in AB-28 According to Land (\%)

As it is seen in Graphic 1, 48\% of enterprises in AB-28, $8 \%$ of enterprises in North-West Europe have less than 2 hectares of production land. These enterprises sustain their activities based on family labor force. Land sizes of enterprises which conduct family farming in European Union are quite different when considered in the sense of employment capacity and size of enterprise [10]. Family farming is carried out not only in small but also in big enterprises.

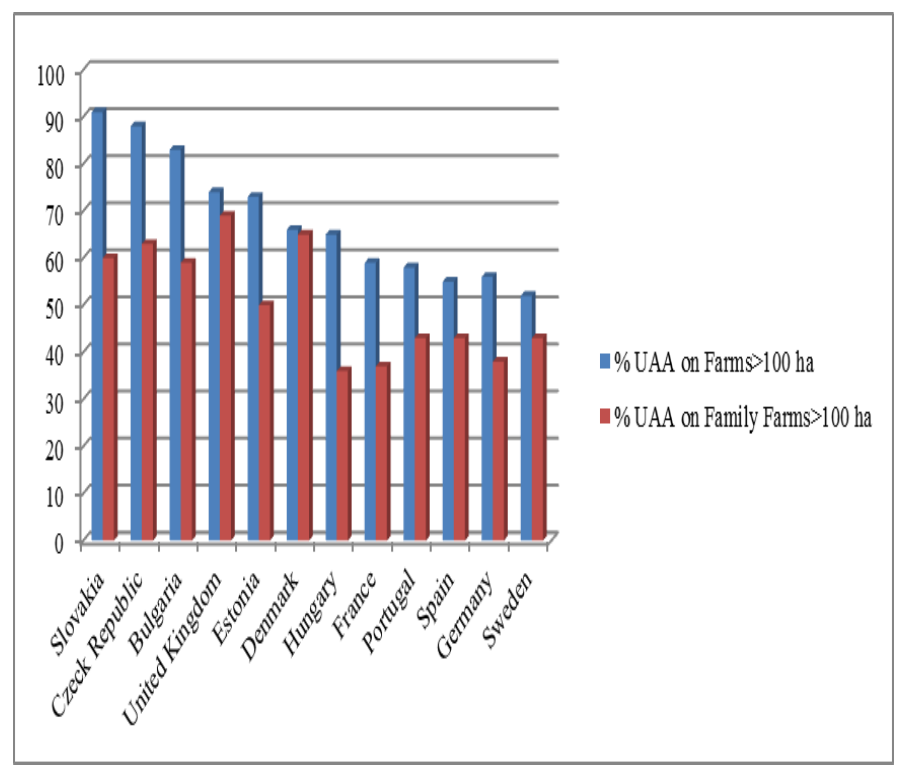

Resource: [9].

Fig. 2 Distribution of Enterprises which run Agricultural Area of more than 100 Hectare in AB-28 and make Family Farming (\%)

According to Graphic 2, more than 50\% of total enterprises are composed of enterprises which have more than 100 ha. And more than $40 \%$ of these enterprises are composed of family farming. The number of enterprises which conduct family farming is quite a lot in England and Denmark [9].

\section{B. Family Farming in Mexico}

There are 5,4 million agricultural enterprises in European Union averagely and $81,3 \%$ of these enterprises are enterprise owners. Mexico Ministry of Agriculture, Husbandry, Rural Development, Fishery and Nutrition [11] classified enterprises conducting family farming in three groups namely subsistence family farming, family farming in transition process and consolidated family farming [11], [12].

TABLE I

AVERAGE SIZE OF FAMILY ENTERPRISES IN MEXICO (HA) AND AVERAGE INCOME (\$)

\begin{tabular}{rrr}
$\begin{array}{r}\text { Subsistence } \\
\text { Family } \\
\text { Farming }\end{array}$ & $\begin{array}{r}\text { Family } \\
\text { Farming in } \\
\text { Transition } \\
\text { Process }\end{array}$ & $\begin{array}{r}\text { Consolidated } \\
\text { Family Farming }\end{array}$ \\
17,4 & 56,8 & 25,8 \\
\hline 3,4 & 5 & 4,7 \\
\hline 1308 & 2726 & 3403 \\
\hline
\end{tabular}

Resource: [11], [12]

As it is seen in Table 1, family farming in Mexico was calculated according to land size and income resources. This classification contributes to policy makers and rural investors. Mexico Ministry of Agriculture, Husbandry, Rural Development, Fishery and Nutrition [11] support enterprises conducting family farming with various programs such as equipments and infrastructure investments, capacity increase [13].

\section{Family Farming in Brazil}

For enterprises to be regarded as family farming in Brazil; they should be run by the family, have 5-100 ha land and their income should only be obtained from farming income.

TABLE II

AVERAGE ENTERPRISE SIZE (HA) OF FAMILY ENTERPRISES IN BRAZIL AND AVERAGE ENTERPRISE INCOME (\$)

\begin{tabular}{ccccccc}
\hline & $\begin{array}{c}\text { Number of } \\
\text { Farms }\end{array}$ & $\begin{array}{c}\text { Average } \\
\text { Farm Size } \\
\text { (ha) }\end{array}$ & $\begin{array}{c}\text { Average } \\
\text { Income } \\
\text { per } \\
\text { Farm }(\$)\end{array}$ & $\begin{array}{c}\text { Family } \\
\text { Farm } \\
(\%)\end{array}$ & $\begin{array}{c}\text { Share } \\
\text { of } \\
\text { Land } \\
(\%)\end{array}$ & $\begin{array}{c}\text { Share of } \\
\text { Production } \\
\text { Value }(\%)\end{array}$ \\
\hline $\begin{array}{c}\text { Family } \\
\text { Farm }\end{array}$ & 4.367 .902 & 18,4 & 13.884 & 84,4 & 24,3 & 37,5 \\
\hline Other & 807.587 & 309,2 & 126.628 & 15,6 & 75,7 & 62,5 \\
\hline Total & 5.175 .489 & 31,8 & 31.283 & 100 & 100 & 100 \\
\hline
\end{tabular}

Resource: [12]

In Brazil which is at the top of the list in agricultural production order in The World, although family farming surpasses compared to other enterprises in the sense of production value. $24,3 \%$ of total land is operated in Brazil and $37,5 \%$ of total agricultural disposal [14].

\section{Family Farming in China}

There is still no clear definition of family farming in China. However, when the general structure of Asia countries are considered; family farming is considered as enterprises which have less than 2 hectares of land, managed by household and 
used family labor force in it [15]. Average size of enterprise is 0,5 hectares. It is estimated that there are 193 million enterprises which have less than 2 hectares of land [15], [16], [17]. $95 \%$ of the total land in China is run by small enterprises [18].

\section{E. Family Farming in India}

There is no official definition of family farming in India. There are nearly 117 million enterprises which have less than 2 hectares and it composes $80,6 \%$ of total enterprises and $43,5 \%$ of the total land is run by family farming [19], [16]. Classification of agricultural enterprises in India is done as small, medium-sized and big enterprises and given in Table 3.

TABLE III

DISTRIBUTION OF ENTERPRISES IN INDIA (\%)

\begin{tabular}{lll}
\hline & \% Distribution & \% Land Distribution \\
\hline Small (<2 ha) & 80,6 & 43,5 \\
\hline $\begin{array}{l}\text { Medium-sized (2-10 } \\
\text { ha) }\end{array}$ & 18,1 & 44,7 \\
\hline Big (>10 ha) & 1,3 & 11,8 \\
\hline
\end{tabular}

Resource: [16]

As it is seen in Table 3, although small enterprises in India are more than medium-sized enterprises, they are close to each other in the sense of agricultural land they run. Since they cannot attain modern techniques and grow scale, incomes of small enterprises are insufficient [19].

\section{F. Family Farming in Turkey}

$23 \%$ of the population in Turkey lives in rural area and live off agricultural production. The share of agriculture in employment is $24 \%$. Although the share of agriculture has decreased nearly $50 \%$ in the last 20 years in employment, still one person out of 4 is employed in agriculture sector. $51,4 \%$ of population is man labor force, $46,1 \%$ is woman labor force and $2,5 \%$ is child labor force in agriculture sector. $47 \%$ is unpaid family worker [5].

There are nearly 3 million agricultural enterprises in Turkey and generally classified according to their size. According to Law of Giving Land to the Farmer no 4753, enterprises which have between 0-500 decare of land are small-scaled agricultural enterprises and named as family farming. Classification of enterprises is given in Table 4. According to this classification, $99,28 \%$ of enterprises conduct family farming [5].
TABLE IV

\begin{tabular}{lcccc}
\multicolumn{5}{l}{ LAND USE STATUS ACCORDING TO ENTERPRISE SIZES IN TURKEY } \\
\hline \begin{tabular}{l} 
Size $\begin{array}{l}\text { Enterprise } \\
\text { (da) }\end{array}$ \\
\hline Total
\end{tabular} & $\begin{array}{c}\text { Number of } \\
\text { Enterprises } \\
(\mathrm{da})\end{array}$ & $\%$ & Total Land & $\%$ \\
\hline-5 & 3.022 .127 & & 184.348 .223 & \\
\hline $5-9$ & 178.006 & 5,89 & 481.987 & 0,26 \\
\hline $10-19$ & 290.461 & 9,61 & 1.952 .471 & 1,06 \\
\hline $20-49$ & 539.816 & 17,86 & 7.378 .022 & 4 \\
\hline $50-99$ & 950.840 & 31,46 & 29.531 .619 & 16,02 \\
\hline $100-199$ & 560.049 & 18,53 & 38.127 .032 & 20,68 \\
\hline $200-499$ & 327.363 & 10,83 & 43.884 .395 & 23,8 \\
\hline $500-999$ & 153.685 & 5,09 & 42.075 .497 & 22,82 \\
\hline $1000-2499$ & 17.429 & 0,58 & 11.218 .554 & 6,09 \\
\hline $2500-4999$ & 4.199 & 0,14 & 5.476 .930 & 2,97 \\
\hline $5000-+$ & 222 & 0,01 & 695.541 & 0,38 \\
\hline & 57 & 0 & 3.526 .175 & 1,91 \\
\hline
\end{tabular}

Resource: [20].

As it can be understood from Table 4, nearly $84 \%$ of enterprises are below 100 decare according to 2001 Agriculture count. These enterprises conduct $42 \%$ of total agricultural land [21], [22].

TABLE V

DISTRIBUTION OF ENTERPRISES ACCORDING TO ECONOMIC SIZE AND TYPOLOGY CLASSIFICATION (\%)

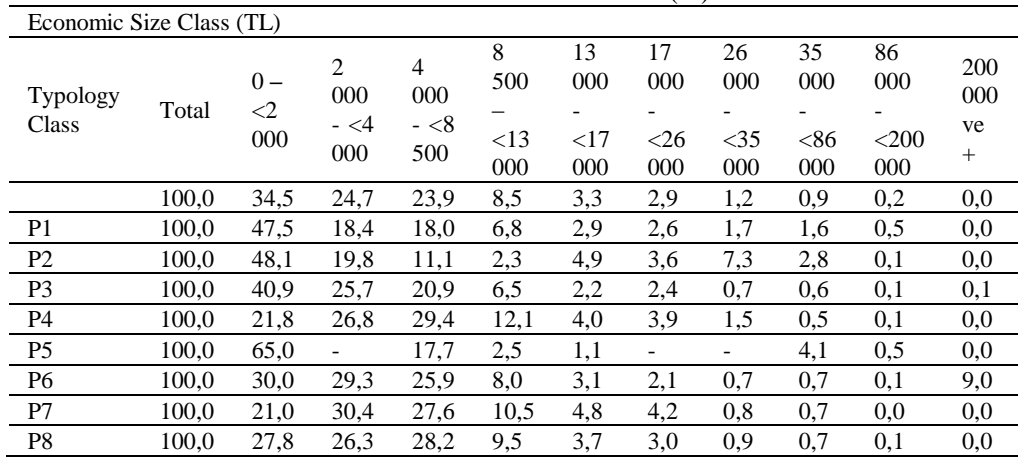

\begin{tabular}{ll}
\hline P1: Specialist Field Crops Farming & P2: Specialist Horticulture \\
\hline P3: Specialist Permanent Crops & P4: Specialist livestock holdings \\
\hline P5: Specialist granivors & P6: Mixed Cropping \\
\hline P7: Mixed livestock holdings & P8: Crop production or animal \\
& production or Sheep and goat \\
& Breeding \\
\hline
\end{tabular}

Resource: [5].

As it is seen in Table 5, enterprises which make agricultural production generally have $0-8500 \mathrm{TL}$ income. $34,5 \%$ of total enterprises have $0-<2.000 \mathrm{TL}, \% 24,7$ have $2.000-<4.000 \mathrm{TL}$, $\% 23,9$ have $4.000-<8.500 \mathrm{TL}$ and $\% 8,5$ have 8.500$<13.000 \mathrm{TL}$ income [5].

Family farming which has such an important place still has no official definition. However in the report of Ninth Development Plan Vegetative Production Specialization Commission, when "population per enterprise in size of agricultural enterprises" are considered, it can be said that agriculture in Turkey are in the level of subsistence enterprise. Great majority of agricultural population make traditional production and enterprises are small family enterprises [23]. 


\section{SOME Structural Factors Which EFFECT FAMILY FARMING IN TURKEY}

In Turkey, primarily Ministry of Food, Agriculture and Husbandry; universities, research institutions and other nonorganizational institutions observe and analyze socioeconomic structure of "National Family Farming" with workshop, congress, panel and researches. In this sense, macro level studies are carried out in the frame of family farming about organization, financing and supports, marketing and product evaluation, share of woman in family farming, child labor, education, publication and consulting. In the sense of enterprises about family farming, micro level studies are carried out and there is a need for especially contribution in sustainability and supply of family requirements which are basic aims of international family farming.

\section{Results AND SUgGestions}

Nearly $47 \%$ of world population lives in rural area (World Bank, 2014). Great majority of this population live off agricultural production. Enterprises which make agricultural production generally do family farming. $72 \%$ of enterprises which conduct family farming in 161 countries have less than 2 hectares land, $12 \%$ have 1-2 ha land [1]-[4]. These enterprises run $56 \%$ of total agricultural land and use family labor. When agricultural data in the world are considered, it is seen that great majority of agricultural production is met by family farming. Labor force in family farming is quite important for being stable capital. 23\% of population in Turkey lives in rural area [5]. This population generally works in agricultural sector. There are 3 million agricultural enterprises in Turkey and 99,28\% of these enterprises do family farming. $84 \%$ of these enterprises have less than 10 decare of production land. They run $42,02 \%$ of total land [5]. Family farming has a dominant role in the world and in Turkey. Therefore first of all definition of family farming should be done in the world and in Turkey. Family farming is important for enabling balance of urban and rural area. However, with the effect of popular life style of young section, there is migration from rural to urban area due to insufficient service opportunities. Policies should be developed in order to prevent migration of active population from village to cities. Awareness is raised in public opinion through regulations such as symposium, congress, workshop, exhibition and local product markets etc. and the importance of family farming should be expressed. While policies are made in order to make larger-scale agriculture enterprises in recent years in Turkey, policies should be made considering sustainability and future of family farming. Moreover, rural development institutions should give priority to projects which support family farming.

\section{REFERENCES}

[1] FAO, 2013a. 2000 World Census of Agriculture: Analysis and international comparison of the results 1996-2005. Rome, FAO.

[2] Hazell, Poulton, Wigginsand Dorward, 2010. The Future of small Farms, Trajectories and Policy Priorities. World development 38(10): 1349-1361. https://doi.org/10.1016/j.worlddev.2009.06.012

[3] IFAD 2011. Rural Poverty Report, 2011, http://www.ifad.org/rpr/2011. (Access time: 22 March 2011).

[4] Lowder S. K., Skoet J., Singh S. 2014. "What do We Really Konow About the Number and Distriution of Farms and Family Farm in the Worldwide?" Background paper for The State of Food and Agriculture 2014. ESA Working Paper No. 14-02. Rome, FAO.

[5] TUIK, 2014. http://www.tuik.gov.tr/Start.do (Access time: 15 April 2014).

[6] Anonim 2014 a, http://www.fao.org/3/a-as281o.pdf (Access time: 11 May 2014).

[7] FAO 2013b. "The State of Food Insecurity in the World". The multiple dimensions of food security. Rome, FAO.

[8] Sarkar B., 2014."Concepts of Family Farming". Indian Statistical Institute, Fas.

[9] Davidova S. and Thomson K., 2010. Family Farming in Europe: Challenges and Prospect. Directorate General for Internal Policies Policy Department B: Structural and Cohesion Policies Agriculture and Rural Development.

[10] Hennessy T., 2014. Eropean Parliament, Directorate General For Internal Policies Policy Department B: Structural And Cohesion Policies, Agriculture, Cap 2014-2020 Tools to Enhance Family Farming Opportunities and Limitsiln-Depth Analysis. http://europarl.europa.eu/ (Access time: 3 November 2014).

[11] SAGARPA, 2014. http://www.gob.mx/sagarpa (Access time: 19 November 2014).

[12] FAO 2012. Regional Office for Latin America and the Caribbean. 2012. "Family Farming in Brazil". Family Farming Newsletter for Latin America and the Caribbean. Temmuz-Eylül 2012.

[13] FAO 2013c. Regional Office for Latin America and the Caribbean. 2013. "Family Farming in Mexico". Family Farming Newsletter for Latin America and the Caribbean. April-June 2013.

[14] Anonim 2014b. http://www.fao.org/fileadmin/user_upload/iyff/pdf/Family_Farming_lea flet-print-tu.pdf (Access time: 30 March 2014).

[15] Thapa G. andGaiha R., 2011. "SmallholderFarming in Asia and the Pacific: Challenges and Opportunities" Paper presented at the IFAD Conference on New Directions for Small holder Agriculture 24-25 January, 2011.

[16] NCEUS 2008. National Commission for Enterprises in the Unorganised Sector. A special programme for marginal and small farmers. New Delhi, India. OECD, FAO, 2014. "Agricultural Outlook 2014-2023”.

[17] Chen, K. Z., Reardon, T. A., Hu, D., 2013. "Linking small holders with rapidly transforming markets: Modernizing small holders agriculture through value chain development in China".

[18] Fan, S. and Chang-Kang, C., 2003. Is small beautiful? Farm size, productivityandpoverty in Asianagriculture. $25^{\text {th }}$ International Conference of AgriclturalEconomists, 17 Haziran 2013, Durban, South Africa.

[19] OECD, 2014. http://stats.oecd.org/ http://www.gob.mx/sagarpa (Access time: 4 September 2014)

[20] TUiK, 2001. Results of General Agriculture Count, Survey of (Household) in Agricultural Enterprises, Land Use Statistics according to Enterprise Size.

[21] TUIK, 2006.www.tuik.gov.tr/PreHaberBultenleri.do?id=3977 (Access time: 07 July 2006).

[22] Çivioğlu S.,Tatlıcan A., Kıymaz T., 2014. Gelişmekte Olan Ülkeler ve Aile Çiftçiliğine Yönelik Politikalar. Ulusal Aile Çiftçiliği Sempozyumu (s. 165-169). Ankara: FAO-SEC.

[23] DPT, 2007. Ninth Development Plan (2007-2013). Report of Vegetative Production Specialization Commission. 